\title{
The Contribution of Self-Confidence and Emotional Intelligence Toward Students' Interpersonal Communication Anxiety and their Implications in Counseling and Counseling Services
}

\author{
Teri Santera ${ }^{1}$, Neviyarni $^{2}$, Afdal $^{3}$ \\ ${ }_{1,2,3}$ Universitas Negeri Padang \\ *Corresponding author, e-mail: santera.teri@yahoo.com
}

\begin{abstract}
This research aims to describe the contribution of self-confidence and emotional intelligence Toward Students' Interpersonal Communication Anxiety. This research uses a descriptive correlational quantitative method. The study sample was 100 students of the Senior High School Mahdaliyah Jambi City. This research uses a quantitative approach with descriptive methods. This study also uses a correlational method, with the analysis technique using simple regression and multiple regression which aims to test the contribution of two independent variables to one dependent variable. The variables in this study consisted of three, namely: self-confidence (X1) and emotional intelligence $(\mathrm{X} 2)$ which were independent variables, and student interpersonal communication anxiety $(\mathrm{Y})$ was the dependent variable. The results of this study indicate that self-confidence and emotional intelligence together have an effect on students' interpersonal communication anxiety by $164.5 \%$. The implication of the results of this study can be used as a needs analysis in making the Guidance and Counseling service program at Senior High School Mahdaliyah Jambi City.
\end{abstract}

Keywords: Self-Confidence, Emotional Intelligence, Interpersonal Communication Anxiety.

How to Cite: Teri Santera, T., Neviyarni, N., Afdal, A. (2020). The Contribution of SelfConfidence and Emotional Intelligence Toward Students' Interpersonal Communication Anxiety and their Implications in Counseling and Counseling Services. International Journal of Applied Counseling and Social Sciences, 2 (1): pp. 67-72, DOI: https://doi.org/10.24036/005398ijaccs

This is an open access article distributed under the Creative Commons 4.0 Attribution License, which permits unrestricted use, distribution, and reproduction in any medium, provided the original work is properly cited. $\odot 2021$ by Author

\section{Introduction}

Interpersonal communication is defined as "The procedure by which people swap information, feelings and impart through verbal, and non-verbal messages" (Sethi, D. and Seth, 2009). In addition, communication is defined as, "A transactional process involving cognitive sorting, selecting, and sharing of symbols in such a way as to help another elicit from his own experiences a meaning or responses similar to that intended by the source" (Rakhmat, 2005). However, anxiety often causes someone to be reluctant to communicate.

Interpersonal communication anxiety is actually natural for individuals to feel if they have not been in an excessive state. However, if it is pathological, it will be very worrying. Many problems will be faced by individuals who are all serious in nature, for example individuals will avoid communicating with other people, or in public, which as a result will make individuals away from social life and avoid 
communication. While individuals who experience a lack of communication will be in a less recognizable personal position, creating a blur of responsibility that makes the individual feel guilty even though he has made many mistakes, makes the individual aggressive, often steals and damages, and loses a sense of social responsibility Barseli et al., 2019). Anxiety that is meant if it occurs excessively and uncontrollably will be bad and even detrimental to those who experience it, and this condition often causes stress. Meanwhile, Stress is an adaptive response to an external situation that results in physical and psychological aberrations (Syahniar, 2017).

Research conducted in the United States by MC Croskey showed 10-20\% of the population experienced communication apprehension, which is a condition where a person feels anxious about communicating, both in formal and informal situations, individually or in groups. This study also explains that people who experience fear of interpersonal communication at school tend to be lazy so they also tend to fail academically.(Sofyan et al., 2015). Research conducted by Yulia Putri Ayuningdyah in 2009 which stated that of the 30 students who conducted the research, 24 students often experienced interpersonal communication anxiety.

Individuals who experience interpersonal communication anxiety are influenced by low selfesteem(Rakhmat, 2005). In line with this, Laxer stated that low self-confidence in individuals causes individuals to tend to see their weaknesses and perceive these weaknesses as something that is disturbing (Purwanto, 2004). someone with low self-confidence or loss of self-confidence, has negative feelings about himself, and has weak belief in his own abilities and also has inaccurate knowledge of the capacities that exist in him (Neviyarni, 2018). In a state of lack of confidence, a person will find it difficult to integrate with their social environment and will be in worry, anxiety, and distance themselves from social life.

Factors that affect other interpersonal communication anxiety, such as in achieving school achievement, for example, too. The association of students while in the school environment and when students are outside the school will greatly influence students in achieving achievement (Suhendra, 2016). This is in line with the opinion that interpersonal communication anxiety is also influenced by emotional intelligence (Suliana, 2018). Communication anxiety is influenced by two factors, namely emotion (emotional intelligence) and motivation (McCroskey, 1977). And emotional intelligence greatly affects how well a person has an intimate relationship or communicates with other people (Papalia Olds Feldman, 2009). In communication anxiety, emotional intelligence will deliver a person so that they can place their emotions in the right portion, sort out satisfaction and set the mood (Ulya Illahi, 2018).

Emotionally intelligent people will be able to control their feelings, control their behavior, and think positively, and be calmer in acting and behaving, so Ema Uzlifatul (2013) explains that emotionally intelligent individuals are more able to be in a social environment and will not be in communication anxiety. because it is able to express emotions spontaneously, can determine exactly when and to what extent it is necessary to be involved in social problems, and can participate in providing solutions or solutions needed when communicating with others.

Next, in order to overcome communication anxiety and the factors that influence it, it is necessary to have BK services (guidance and counseling). The assistance services provided are related to the development of effective daily living conditions (KES) and handling of disturbed daily effective living conditions (KES-T), both individually and in groups (Hasanah, 2018). BK services are an integral part of education by facilitating students, in order to achieve complete and optimal student development with an independent personal focus and being able to control themselves(Prayitno, 2013). In particular, BK teachers or counselors can focus on programming in the field of personal and social development, so that schools can again function as formal institutions that become a forum for developing student potential and self-actualization (Afdal, et al., 2018). because the real function of education is to help students achieve their maximum growth.

The results of data collection and processing are obtained through research instruments that have been considered by experts. This study describes how self-confidence and emotional intelligence contribute to communication anxiety. The implication of this research is to provide input in overcoming 
student communication using BK services in schools because the education system in Indonesia long ago established guidance and counseling services as an integral part of education to create independent and optimally developing students.(Afdal, 2015). The results of this research in the future for future researchers can be used as a reference if they are going to create a counseling guidance service program to overcome and reduce interpersonal communication anxiety in students.

\section{Method}

This study uses a quantitative approach with a descriptive correlational type of method to describe the contribution of self-confidence and emotional intelligence to communication anxiety. The study population was 134 students in Mahdaliyah MAS Jambi City, while the sample was 100 students who were selected using simple random sampling technique. The instrument used was a questionnaire of self-confidence, emotional intelligence, and interpersonal communication anxiety which was compiled using a Likert scale model and given to the sample studied. The data analysis used descriptive statistics, simple regression and multiple regression. The total validity of the total self-confidence variable (standard standard) was 0.503 , the emotional intelligence variable (standard) was 0.430 , and the interpersonal communication anxiety variable was 0.675 .

\section{Results and Discussion}

The data in this study include the variable self-confidence (X1), emotional intelligence (X2), and interpersonal communication anxiety $(\mathrm{Y})$. The following is a description of the research data.

1. Confidence $(\mathrm{X} 1)$

The self-confidence data description of 100 respondents can be seen in Table 1 .

Table 1. Frequency distribution and self-confidence percentage

\begin{tabular}{clcc}
\hline Score Interval & \multicolumn{1}{c}{ Category } & Frequency & $\%$ \\
\hline$\geq 73$ & Very High (ST) & 0 & 0 \\
$59-72$ & Height (T) & 2 & 2 \\
$45-58$ & Medium (S) & 13 & 13 \\
$31-44$ & Low (R) & 63 & 63 \\
$\leq 30$ & Very Low (SR) & 22 & 22 \\
& Total & 100 & 100 \\
\hline
\end{tabular}

Table 1 Table 1 shows that most of the students have low self-confidence, namely $63 \%$, some other students are in the very low category, namely $22 \%$, in the medium category it is $13 \%$, and in the high category it is $2 \%$. The results of the research data analysis showed that on average the overall student confidence was in the low category. This explains that students' self-confidence is poor in reducing interpersonal communication anxiety, meaning that aspects of student self-confidence have not developed optimally. This condition of low student self-confidence needs to be a concern so that it can be optimized, so that these aspects of self-confidence can be developed and increased in reducing interpersonal communication anxiety.

2. Emotional Intelligence (X2)

Description of emotional intelligence data, amounting to 100 respondents, can be seen in Table 2 . 
Table 2. Distribution of Frequency and Percentage of Emotional Intelligence

\begin{tabular}{clcc}
\hline Score Interval & \multicolumn{1}{c}{ Category } & Frequency & $\%$ \\
\hline$\geq 146$ & Very High (ST) & 0 & 0 \\
$118-145$ & Height (T) & 6 & 6 \\
$90-117$ & Medium (S) & 12 & 12 \\
$62-89$ & Low (R) & 61 & 61 \\
$\leq 61$ & Very Low (SR) & 21 & 21 \\
& Total & 100 & 100 \\
\hline
\end{tabular}

Table 2 above shows that most students have low emotional intelligence, namely $61 \%$, some other students have very low emotional intelligence, namely $21 \%$, then $12 \%$ have moderate emotional intelligence and $6 \%$ have high intelligence. From the research data above, it appears that the condition of students' emotional intelligence can be said to be bad. Thus, it is very important to be a concern because emotional intelligence is a skill that is indispensable, especially in social life. Individuals have high emotional intelligence socially stable, sociable, humorous, not easily afraid or anxious which of course will have a sense of comfort towards themselves, other people and their environment.

3. Interpersonal Communication Anxiety (Y)

Descriptions of data on interpersonal communication anxiety, amounting to 100 respondents, can be seen in Table 3.

Table 3. Frequency distribution and percentage of interpersonal communication anxiety

\begin{tabular}{clcc}
\hline Score Interval & \multicolumn{1}{c}{ Category } & Frequency & $\mathbf{\%}$ \\
\hline$\geq \mathbf{1 1 0}$ & Very high & 15 & 15 \\
$\mathbf{8 9 - 1 0 9}$ & High & 78 & 78 \\
$\mathbf{6 8 - 8 8}$ & Moderate & 7 & 7 \\
$\mathbf{4 7 - 6 7}$ & Low & 0 & 0 \\
$\leq 46$ & Very low & 0 & 0 \\
& Total & 100 & 100 \\
\hline
\end{tabular}

Table 3 above shows that most of the interpersonal communication anxiety is in the high category, which is $78 \%$, the very high category is $15 \%$, and the moderate category is $7 \%$. The results of the research data analysis show that on average the overall interpersonal communication anxiety is in the high category. Based on the achievement of each indicator, it is known that all indicators are in the high category. These results illustrate that the students' interpersonal communication anxiety at Madrasah Aliyah Mahdaliyah Jambi City is too excessive or very bad for student development. Interpersonal communication anxiety that can have a negative effect is referred to here as excessive interpersonal communication anxiety,

Table 4. Results of Contribution Analysis of Self-Confidence (X1) and Emotional Intelligence (X2) on Students' Interpersonal Communication Anxiety (Y)

\begin{tabular}{cccc}
\hline Variable & Unstandardized Coefficients & $\mathrm{t}$ & Sig. \\
& $\mathrm{B}$ & & \\
\hline (Constant) & 132,485 & 60,447 & 0.000 \\
X1 & -0.335 & $-3,302$ & 0.001 \\
X2 & -0.205 & $-4,172$ & 0.000 \\
\hline
\end{tabular}


Table 4 above shows that the contribution of the two variables $X$. If seen from the results of the multiple regression test, the value of the $t$ test coefficient of emotional intelligence is greater than the value of the $t$ test coefficient of confidence. The two $X$ variables both make a significant contribution to interpersonal communication anxiety. The contribution of emotional intelligence is slightly greater than the contribution of self-confidence to interpersonal communication anxiety.

The data above also illustrates self-confidence and emotional intelligence collectively contribute to students' interpersonal communication anxiety. That is,Self-confidence and emotional intelligencehas meaning for the communication anxiety felt by students. The level of student interpersonal communication anxiety is not only a contribution of one variable, but is jointly influenced byselfconfidence and emotional intelligence. In other words, that by the wayconfidence then the students' interpersonal communication anxiety is getting lower. This means variableSelf-confidence and emotional intelligence will be more effective if combined together as a predictor to reduce students' interpersonal communication anxiety than just one variable.

\section{Conclusion}

Based on the findings and discussion of the research results, the following conclusions can be made: (1) the average student confidence in MAS Mahdaliyah Jambi City is in the low category, (2) the average emotional intelligence of students in Mahdaliyah MAS Jambi City is at low category, (3) the average interpersonal communication anxiety of students at MAS Mahdaliyah Jambi City was in the high category, (4) self-confidence gave an effect of $58.2 \%$ on interpersonal communication anxiety. This means that interpersonal communication anxiety can be influenced by self-confidence. It can be concluded that the lower the self-confidence, the higher the students' interpersonal communication anxiety, (5) emotional intelligence has an effect of $60.6 \%$ on interpersonal communication anxiety. This means that interpersonal communication anxiety can be influenced by emotional intelligence. It can be concluded that the lower the emotional intelligence, the higher the students' interpersonal communication anxiety, and (6) self-confidence and emotional intelligence together have a $64.5 \%$ effect on interpersonal communication anxiety.

\section{References}

Afdal, A. (2015). Collaborative: A Framework for Future Counselors. Journal of Counseling and Education, 3 (2), 1.https://doi.org/10.29210/12400

Afdal, Hariko, R., Salmi. (2018) Hubungan kontrol diri dengan perilaku bullying Siswa. Jurnal Ilmiah Counsellia, Volume 8 No.2, http://e-journal.unipma.ac.id/index.php/IBK DOI: 10.25273/counsellia.v8i2.2693

Barseli, M., Sembiring, K., Ifdil, I., \& Fitria, L. (2019). The concept of student interpersonal communication. 129-134.

Hasanah, A. Ilyas, A. Afdal. (2018) Student Creativity and the Efforts of Guidance and Counseling Teachers / Counselors in Its Development. Guidance and Counseling Journal 7 (1).

Illahi, U. Neviyarni S. Said, A, Ardi, Z. (2018). The relationship between emotional intelligence and adolescent aggressive behavior and its implications in guidance and counseling. JRTI (Indonesian Action Research Journal. Volume 3. Number 2, http://jurnal.iicet.org/index.php/jit

McCroskey, J. (1977). Oral Communication Apprehension: a Summary of Recent Theory and Research. Human Communication Research. Vol. 4, No.

Neviyarni, S. (2018). The confidence of Aisyiyah orphanage adolescents and their implications for Guidance and Counseling services. 3, 77-83.

Papalia, D. E. (2009). Human Development (Perkembangan manusia, Edisi 10, Buku 2). Jakarta: Salemba Humanika

Prayitno. (2013). Integrity Counseling. UNP Press. 
Purwanto, MA (2004). The Relationship between Self-Control and Interpersonal Communication Anxiety. In the Faculty of Psychology (UGM Issue).

Rakhmat, J. (2005). Psychology of Communication. Rosdakarya youth.

Sethi, D. dan Seth, M. (2009). Interpersonal Communication: Life blood of an Organization. The International Undergraduate Program(IUP) Journal of Soft Skill, Vol. 3 (4).

Sofyan, S., Rapi, M., \& Afiif, A. (2015). The Influence of Communication Anxiety on Academic Achievement of Students of the 2013 Biology Education Department, Tarbiyah and Teaching Faculty, Uin Alauddin Makassar. Journal of Biotech, 3 (2), 133.https://doi.org/10.24252/jb.v3i2.1102

Suliana, WDH \& I. (2018). Relationship between Emotional Intelligence and Students' Social Ability in the VII Grade School Environment of SMP Negeri 03 Mukomuko. Scientific Journal "Guidance and Counseling, Vol. 1

Suhendra, M. Neviyarni S. \& Ahmad, R. (2016). The Contribution of Achievement Motivation to Student Self-Regulation at Madrasah Aliyah Negeri 2 Payakumbuh and its implications for guidance and counseling services. Journal of the Counselor. Vol. 5 http://ejournal.unp.ac.id/index.php/konselor

Syahniar, Ifdil, Ardi,Z. (2017). The Responsibility of Counselor and Education in Millennium Era. International Counseling and Education http://bk.fip.unp.ac.id/ices2017 I pp: 4 